\title{
Agência das Crianças / Children's Agency
}

https://doi.org/10.21814/uminho.ed.36.2

\section{David Oswell}

Goldsmiths, University of London, United Kingdom 



\section{Agência Infantil}

A ideia de agência infantil tem uma longa história, mas ganhou força em meados dos anos 1980 e início dos anos 1990 com o trabalho sociológico de Jens Qvortrup, Leena Alanen, Chris Jenks, Allison James, William Corsaro, Alan Prout, entre outros.

Neste momento, há duas correntes de concetualização que, felizmente, caminham lado a lado (embora uma ocluída pela outra), mas que, numa reflexão mais aprofundada, se percebe não serem muito distintas acerca da ação das crianças, com filiações teóricas e filosóficas também muito distintas.

Por um lado, existe o que podemos chamar de programa forte para a agência infantil e, por outro, um infra-paradigma, que às vezes é referido como " $a$ nova onda". O programa forte da agência infantil é expresso com mais força na obra editada por Allison James e Alan Prout, Construindo e Reconstruindo a Infância (1990), que apresentou um "novo paradigma" para a Sociologia da Infância e na qual o argumento para a agência infantil é sustentado pelo trabalho teórico do sociólogo Anthony Giddens sobre a dualidade de estrutura e agência. Nesse modelo, a infância é entendida como uma faceta da estrutura social e como uma variável de análise social (ao lado, por exemplo, de raça, género e sexualidade), mas o que é uma criança, os significados atribuídos à infância (por exemplo, "inocência", "pureza" e "ingenuidade") e a regulamentação do que as crianças podem ou não fazer na sociedade não thes é simplesmente imposto, como se elas fossem passivas e determinadas pela estrutura social. Ao contrário, as crianças são vistas como ativas na construção da sociedade, ou seja, como tendo agência, de modo que ajudam reflexivamente a moldar e determinar a estrutura social. Neste entendimento teórico da agência das crianças, há uma forte afirmação ontológica sobre o que as crianças são e qual o papel que podem desempenhar na sociedade. Neste modelo, as crianças não podem ser vistas simplesmente em termos do seu crescimento ou desenvolvimento até à idade adulta, entendidas, não apenas, em termos da sua diferença relativamente aos adultos, mas também em termos do que os adultos possuem (por exemplo, racionalidade, responsabilidade e cidadania política) e de que elas parecem necessitar. 0 forte argumento para a agência das crianças é, portanto, quer uma reivindicação do seu poder para moldar a sociedade, 
mas também uma exigência por uma maior compreensão e conhecimento acerca do modo como contribuem para a construção da sociedade.

O programa forte da agência das crianças tem uma inflexão política e o seu surgimento foi estreitamente alinhado com a Convenção das Nações Unidas sobre os Direitos da Criança (1989) e o enorme crescimento do interesse, preocupação e ação em relação aos direitos políticos e estatuto social das crianças. Mas para que os direitos das crianças pudessem ser mais bem apoiados, estava claro que as crianças precisavam de ser mais ouvidas. O foco teórico na agência das crianças exigiu uma atenção metodológica às experiências das crianças (e perceções) e ao posicionamento das suas experiências (por exemplo, vis-à-vis as experiências e perceções dos adultos), mas também à importância das suas vozes na articulação dessas experiências e perceções. Havia um foco nos mundos sociais das crianças, mas também nos discursos que os moldavam.

O infra-paradigma da agência das crianças desenvolve-se juntamente com o programa forte, mas fica quase invisível sob a superfície desse paradigma dominante. Emerge, em parte, através do trabalho de Prout ou André Turmel, com foco menos nas crianças como indivíduos reflexivos, e mais na consideração de uma mistura de corpos, tecnologias, redes e situações sociais complexas em que as crianças podem ser encontradas. 0 infra-paradigma não afirma a priori uma base ontológica forte das crianças como sujeitos agentes, mas considera as situações sociais empíricas através das quais a agência das crianças é distribuída por uma rede de atores. Esta corrente é fortemente influenciada pelos contributos da teoria ator-rede desenvolvida por Bruno Latour e Michel Callon, mas também pela filosofia de Gilles Deleuze e os estudos feministas de ciência e tecnologia de Donna Haraway. A pesquisa é tipificada por uma ideia de que o mundo social é sempre confuso e híbrido, uma mistura de social, natural e tecnológico, e que a análise social nunca se pode apoiar numa versão eurocêntrica do indivíduo atomístico.

Embora a narrativa do programa forte ainda seja dominante como visão ideológica (até porque tem um refrão poderoso de agência infantil, experiência infantil e voz política infantil), contributos inovadores do infra-paradigma, ou da nova onda, em maneiras diferentes, mas imaginativas, espalharam-se por campos multidisciplinares e investigações sobre crianças e infância. A pesquisa, por exemplo, de Alcinda Honwana sobre jovens soldados em Moçambique, sublinha a vulnerabilidade e a mobilidade fugaz da sua agência. Ela considera como esses jovens demonstram, não um "ativo" 
contra uma agência "passiva", mas sim uma "agência tática" que é menos "heróica" e mais subtil, matizada e muitas vezes reveladora de fraqueza e não de força. Muitas das interessantes pesquisas recentes sobre a agência infantil pluralizaram, quer a variedade e os diferentes tipos de agência desenvolvidos em diferentes situações sociais, mas também destacaram a ambiguidade e a ambivalência da agência, enfrentando um enquadramento puramente "positivo".

\section{Children's Agency}

There is a long history of the idea of children's agency, but it properly and fully became a concept in the mid 1980s and early 1990s with the largely sociological work of Jens Qvortrup, Leena Alanen, Chris Jenks, Allison James, William Corsaro, Alan Prout and others.

Nowadays, there are two strands of conceptualisation, which comfortably co-exist (although one is occluded by the other), but which on closer reflection are very distinct conceptualisations of children's agency with very different theoretical and philosophical origins. On the one hand, there is, what we can refer to as the strong programme for children's agency and, on the other, an infra-paradigm, or what is sometimes referred to as "the new wave".

The strong programme for children's agency is most forcefully expressed in Allison James and Alan Prout's edited collection Constructing and Reconstructing Childhood (1990), which presents a "new paradigm" for the sociology of childhood and in which the argument for children's agency is scaffolded by the theoretical work of the sociologist Anthony Giddens on the duality of structure and agency. In this model, childhood is understood as a facet of social structure and as a variable of social analysis (alongside, for example, race, gender and sexuality), but what a child is, the meanings attached to childhood (for example, "innocence" "purity" and "naivety"), and the regulation of what children may or may not do in society, are not simply imposed on children, as if children were passive and determined through social structure. On the contrary, children are seen as active in the construction of society, so they are seen to have agency, in that they reflexively help to shape and determine social structure. In this theoretical understanding of children's agency, there is a strong ontological claim regarding what children are and what role they are able to play in society. In this model, children cannot simply be seen in terms of their growth or development toward adulthood, understood not only in terms of their difference from adults, 
but in terms of what adults are seen to possess (for example, rationality, responsibility, and political citizenship) and what children are seen to lack. The strong argument for children's agency is thus both a claim for children's power to shape society, but also a demand for greater understanding and knowledge of what children contribute to the making of society.

The strong programme for children's agency has a political consequence and its emergence was closely aligned with the UN Convention on the Rights of the Child (1989) and the huge growth of interest, concern and action regarding children's political rights and social status. But in order that children's rights might be better supported, it was clear that children needed to be better heard. The theoretical focus on children's agency was matched not only by a methodological attentiveness to children's experiences (and perceptions) and the positionality of their experiences (for example, vis-à-vis adults' experiences and perceptions), but also by the importance of children's voices in articulating those experiences and perceptions. There was indeed a focus on the social worlds of children, but also on the discourses shaping those worlds.

The infra-paradigm of children's agency develops alongside the strong programme, but is almost invisible below the surface of that dominant paradigm. It emerges in part through the work of Prout or André Turmel with less focus on children as reflexive individuals than on the mix of bodies, technologies, networks, and complex social situations in which children may be found. The infra-paradigm does not assert a strong a priori ontological foundation of children as agentic subjects, but rather considers the empirical social situations through which children's agency is distributed across a network of actors. This research is heavily influenced by the theoretical writing on actor-network theory developed by Bruno Latour and Michel Callon, but also by the philosophy of Gilles Deleuze and the feminist science and technology studies of Donna Haraway. The research is typified by a sense that the social world is always messy and hybrid, a mix of the social, natural and technological, and that social analysis can never rest on a Eurocentric version of the atomistic individual.

Although the narrative of the strong programme is still dominant as an ideological vision (not least because it has a powerful refrain of children's agency, children's experience and children's political voice), the new offerings from the infra-paradigm, or the new wave, in disparate, yet imaginative ways, have spread across multi-disciplinary fields and investigations of children and childhood. The research, for example, of Alcinda Honwana on 
young soldiers in Mozambique stresses the vulnerability and fleeting mobility of their agency. She considers how these young people demonstrate, not an "active" against a "passive" agency, but rather a "tactical agency" that is less "heroic" and more subtle, nuanced and often from the position of weakness, not strength. Much of the recent interesting research on children's agency has both pluralised the variety and different types of agency deployed in different social situations, but also foregrounds the ambiguity and ambivalence of agency, undermining a purely "positive" framing.

\section{Referências / References}

James, A. \& Prout, A. (Eds.) (1990). Constructing and Reconstructing Childhood: Contemporary Issues in the Sociological Study of Childhood. London: Falmer Press.

Honwana, A. (2005). Innocent and guilty: child-soldiers as interstitial and tactical agents. In A. Honwana \& F. De Boeck (eds.), Makers and Breakers: Children and Youth in Postcolonial Africa (pp. 31-52). Oxford: James Currey.

Oswell, D. (2013). The Agency of Children: From Family to Global Human Rights. Cambridge: Cambridge University Press. 